\title{
The effect of a diet fortified with polyunsaturated fatty acids on the level of selected elements in the myocardium of growing pigs
}

\author{
E. Sawosz ${ }^{1,2}$, E. Kowalczyk ${ }^{2}$, A. Hotowy ${ }^{2}$, R. Lechowski ${ }^{3}$, \\ M. Kleczkowski ${ }^{3}$ and M. Fabijańska ${ }^{1}$
}

\author{
'Department of Animal Feeding and Feed Science, \\ Warsaw Agricultural University \\ Rakowiecka 26/30, 02-258 Warszawa, Poland \\ ${ }^{2}$ Department of Physicochemical Analysis \\ ${ }^{3}$ Faculty of Internal Diseases with Clinics \\ Warsaw Agricultural University \\ Nowoursynowska 166, 02-787 Warszawa, Poland
}

\begin{abstract}
The experiment was carried out on 3 groups of fatteners (Large White $x$ Polish Landrace), 7 per group, housed in individual cages for 102 days from a body weight of 25 to $102 \mathrm{~kg}$. They were fed complete feed containing $4 \%$ of the following types of fats: lard, linseed oil, fish by-product oil. After slaughter, samples of the myocardium were collected from the pigs and the content of elements was determined spectrometrically. It was found that linseed oil added to the mixture significantly $(\mathrm{P}<0.05)$ increased $\mathrm{Fe}$ and $\mathrm{Cr}$ contents, whereas fish by-product oil increased $(\mathrm{P}<0.05)$ the $\mathrm{Mg}$ and $\mathrm{Cr}$ level in dry matter of heart tissue in pigs.
\end{abstract}

KEY WORDS: pigs, heart, elements, polyunsaturated fatty acids

\section{INTRODUCTION}

Additional quantities of minerals are often necessary in animal and human nutrition in order to fully satisfy demand for these elements. The additionally administered compounds may, however, disturb metabolic homeostasis. In particular, elements with a variable valency $(\mathrm{Sc}, \mathrm{Ti}, \mathrm{V}, \mathrm{Cr}, \mathrm{Mn}, \mathrm{Fe}, \mathrm{Co}, \mathrm{Ni}$ and $\mathrm{Cu})$ that catalyze the Fenton reaction may stimulate generation of free radicals under certain 
conditions (Halliwel and Gutteridge, 1990). The availability of the specific cations in sites where they are utilized in the body depends, among others, on the degree of their absorption from the alimentary tract, transport efficiency in system fluids, transport via cellular membranes, and mobility of the accumulated reserves. These processes may be modified to a certain degree by the choice of the appropriate dietary components. It seems that the addition of mineral compounds should be the last resort after utilization of all other possibilities of increasing the effectiveness of their utilization.

The n-3 PUFA contained in linseed and fish oils determine the integrity and permeability of cellular and intracellular membrane structures, transport of lipids via the blood, synthesis of eicosanoids. They also act as signal molecules (Fernandes and Venkatraman, 1993; Clamp et al., 1997). Reibel et al. (1988) demonstrated that dietary n-3 PUFA reduce the $\alpha_{1}$-adregenic inotropic response. Consequently, they can protect the myocardium against the pathophysiological effects of catecholamine release evoked by chronic adrenergic or ischemic stress (Bordoni et al., 1993). It may be therefore supposed that the morphological-functional modification of the myocardium as a consequence of n-3 PUFA supply in the diet may affect the distribution of ions in the examined tissue.

The aim of the experiment was to determine the changes in the contents of selected elements in the myocardium as affected by the use of n-3 PUFA-rich oils in comparison with a diet containing lard.

\section{MATERIAL AND METHODS}

Fatteners (Large White $\mathrm{x}$ Polish Landrace) were divided into 3 groups, 7 animals each, and housed in individual pens for 102 days from a body weight of about $25 \mathrm{~kg}$ to about $102 \mathrm{~kg}$. The animals were fed in the rationed system, using complete feed where the following components were used (\%): wheat meal, 10.0; barley meal, 59.9 ; fat, $4.0 ; \alpha$-tocopherol acetate, $0.30 \%$; mineral-vitamin components: $\mathrm{Ca}_{2} \mathrm{HPO}_{4}, 0.2 ; \mathrm{CaCO}_{3}, 1.0 ; \mathrm{NaCl}, 0.6$; and Optamix PT2 (Polfarm, Grodzisk Maz., Poland), 1.0 , containing ( $\mathrm{g}$ in $1000 \mathrm{~g}$ ): vit. A, $500000 \mathrm{IU}$; vit. $\mathrm{D}_{3}, 00000 \mathrm{IU}$; vit. $B_{1} 0.05$; vit. $B_{2}, 0.2$; biotin, 0.005 ; vit. $B_{12}, 0.0015$; vit. $\mathrm{K}, 0.1$; niacin, 1.5 ; folic acid, 0.01 ; calcium panthotenate, 1 ; choline, $10 ; \mathrm{Mg}, 1 ; \mathrm{Mn}, 2 ; \mathrm{Zn}, 6 ; \mathrm{Se}, 0.02 ; \mathrm{Cu}$, 2 ; $\mathrm{Fe}, 5 ; \mathrm{J}, 0.025$; antioxidant, 10 , lysine, $40 ; \mathrm{CaHCO}_{3}$ up to $1000 \mathrm{~g}$. Different types of fat were used (Table 1): lard, group I; linseed oil, group II; fish by-product oil, group III. The fish by-product oil was obtained from a fish processing plant and contained a mixture of fish and rape oil, obtained as a by-product during canning. At the end of the experiment the pigs were sacrificed by electronarcosis and bleeding. Immediately after death, heart muscle samples were taken, transferred to the laboratory and frozen. 
TABLE 1

Content of fatty acids in different fats and in the unsupplemented mixture, $\%$

\begin{tabular}{|c|c|c|c|c|}
\hline Fatty acids & Lard & $\begin{array}{l}\text { Linseed } \\
\text { oil }\end{array}$ & $\begin{array}{l}\text { Fish by-product } \\
\text { oil }\end{array}$ & $\begin{array}{l}\text { Unsupplemen- } \\
\text { ted mixture }\end{array}$ \\
\hline $14: 0$ & 1.5 & 0.1 & 0.9 & 0.6 \\
\hline $16: 0$ & 23.5 & 5.2 & 6.0 & 16.6 \\
\hline $16: \ln -7$ & 2.7 & 0.1 & 1.3 & 0.9 \\
\hline 18:0 & 12.4 & 5.6 & 1.8 & 7.8 \\
\hline $18: \ln -7$ & 3.2 & 0.6 & 3.3 & 1.5 \\
\hline $18: \ln -9$ & 44.1 & 22.2 & 48.9 & 27.5 \\
\hline $18: 2 n-6$ & 7.5 & 17.3 & 18.3 & 29.6 \\
\hline $18: 3 n-3$ & 0.7 & 47.5 & 5.9 & 13.3 \\
\hline $20: 0$ & 0.2 & 0.2 & 0.4 & 0.2 \\
\hline $20: \ln -9$ & 1.2 & 0.2 & 2.7 & 0.8 \\
\hline $20: 2 n-6$ & 0.4 & 0.1 & 0.2 & 0.2 \\
\hline $20: 4 n-6$ & 0.2 & & 0.1 & \\
\hline $20: 5 n-3$ & & & 1.2 & 0.2 \\
\hline $22: 0$ & & 0.1 & 0.1 & 0.1 \\
\hline $22: \ln -9$ & & & 2.8 & 0.3 \\
\hline $22: 5 n-3$ & 0.1 & & 0.1 & \\
\hline $22: 6 n-3$ & 0.1 & & 1.8 & 0.2 \\
\hline $24: 0$ & & 0.1 & 0.1 & 0.1 \\
\hline $24: \ln -9$ & & & 0.3 & 0.1 \\
\hline others & 2.2 & 0.7 & 3.8 & \\
\hline SFA & 38.0 & 11.3 & 9.3 & 25.4 \\
\hline MUFA & 52.3 & 23.8 & 62.6 & 31.1 \\
\hline PUFA & 9.7 & 64.9 & 28.1 & 43.5 \\
\hline n-6PUFA & 8.1 & 17.4 & 19.1 & 29.8 \\
\hline n-3PUFA & 0.9 & 47.5 & 9.0 & 13.7 \\
\hline
\end{tabular}

The fatty acid level in the feed was determined by gas chromatography on a Hewlett Packard-1580 instrument with an FID detector using a BPX 70 capillary column, $50 \mathrm{~m} \times 0.24 \mathrm{~mm}$ from SGE Inc. Austin (PN-ISO 5509, 1978; PN-ISO $5508,1990)$. The content of elements in lyophilized samples of heart tissue was determined by the spectrometric method of: inductivity couple plasma ICP (Ca, $\mathrm{Fe}, \mathrm{Mg}, \mathrm{P}, \mathrm{S}, \mathrm{Zn}$ ), absorption with electrothermal atomization (Cr) using a Thermo Jarrel Ash instrument, and flame atomization $(\mathrm{Na}, \mathrm{K})$ using a Shimadzu instrument. The samples were prepared with the use of a Milestone microwave mineralization apparatus.

The obtained data were analyzed using one-way ANOVA to determine the significance of differences. When the F-test was significant, it was followed by the multiple range test. The Statgraphics Plus 4.1 statistical software package was employed. 


\section{RESULTS AND DISCUSSION}

It was found that increasing the PUFA supply in the diet did not change the calcium content in the dry matter of myocardium tissue (Table 2). PUFAs, which are not protected from oxidation, may promote lipid peroxidation and degradation of cellular membranes, which can lead to an excessive inflow of $\mathrm{Ca}$ into the

TABLE 2

The level of elements in dry matter of myocardium tissue of fatteners

\begin{tabular}{lcccccc}
\hline Content of & \multicolumn{3}{c}{ Group } & & \multicolumn{2}{c}{ ANOVA } \\
\cline { 2 - 4 } \cline { 3 - 4 } element & lard & linseed oil & fish oil & & SEM & P \\
\hline Ca, mg kg-1 & 210 & 208 & 216 & & 9.54 & NS \\
$\mathrm{P}, \mathrm{g} \mathrm{kg}^{-1}$ & 9.44 & 9.84 & 9.83 & & 0.27 & $\mathrm{NS}$ \\
$\mathrm{Mg}, \mathrm{mg} \mathrm{kg}^{-1}$ & $824^{\mathrm{a}}$ & $842^{\mathrm{ab}}$ & $870^{\mathrm{b}}$ & & 18.53 & 0.023 \\
$\mathrm{~K}, \mathrm{~g} \mathrm{~kg}^{-1}$ & 17.8 & 18.4 & 17.7 & & 0.61 & $\mathrm{NS}$ \\
$\mathrm{Na}, \mathrm{g} \mathrm{kg}^{-1}$ & 3.96 & 4.24 & 4.02 & & 0.12 & $\mathrm{NS}$ \\
$\mathrm{S}, \mathrm{g} \mathrm{kg}^{-1}$ & 8.79 & 9.29 & 9.31 & & 0.35 & 0,054 \\
$\mathrm{Zn}, \mathrm{mg} \mathrm{kg}^{-1}$ & 82.5 & 83.5 & 84.7 & & 2.01 & $\mathrm{NS}$ \\
$\mathrm{Fe}, \mathrm{mg} \mathrm{kg}^{-1}$ & $186.8^{\mathrm{a}}$ & $208.3^{\mathrm{b}}$ & $186.2^{\mathrm{a}}$ & & 9.00 & 0.021 \\
$\mathrm{Cr}, \mathrm{mg} \mathrm{kg}^{-1}$ & $0.073^{\mathrm{a}}$ & $0.098^{\mathrm{b}}$ & $0.095^{\mathrm{b}}$ & & 0.005 & 0.009 \\
\hline
\end{tabular}

a.b $\mathrm{P}<0.05$

cell. In the discussed experiment, vitamin $E$ was supplied in considerable amounts, therefore we may suppose that the obtained results were only a consequence of PUFA n-3 activity (Leibovitz et al., 1990) and not of their oxidized derivatives. The extracellular concentration of calcium should be higher than the concentration inside the cell and the correct relaxation of myocardial cells is ensured additionally by antiportal transport, exchanging $\mathrm{Ca}$ ions that penetrated the cells for extracellular $\mathrm{Na}$ ions. The concentrations of $\mathrm{Ca}$ and $\mathrm{Na}$ outside and inside the cardiocytes has a major influence on the correct function of the myocardium (Lauridsen et al., 1997). In our experiment, no changes in $\mathrm{Na}$ or $\mathrm{K}$ levels in the dry matter of myocardium were found.

The content of $\mathrm{P}$ in myocardium dry matter was also unchanged, which may point to a stable quantitative content of phospholipids in the cells, in contrast to their quality, resulting from the content of different fatty acids (Nalbone et al., 1989). Lack of differences in $P$ content in the examined tissue may be evidence of stability of the process of feeding the Ca pump and energy transfer via AMP, ADP and ATP (Ternouth, 1990). This subject requires, however, more precise studies.

An increase of the $\mathrm{Mg}$ content of the myocardium, as affected by the intake of the feed enriched in fish by-product oil, and especially in n-3 PUFA - eicosapen- 
taenoic (EPA) C 20:5 and docosahexaenoic (DHA) C 22:6, was found. Demaison and Grynberg (1991) noticed that administration of fish oil to rats increased the oxidation of palmitic acid and prevented it from accumulating in heart lipids. $\mathrm{Mg}$ is an element involved in the oxidation of fatty acids and also influences the integrity of cellular membranes, binding phospholipids (Shils, 1997). It is probable that the increase of the EPA and EHA supply in the diet mobilized the accumulation of $\mathrm{Mg}$ in the cell.

The level of $\mathrm{Fe}$ in myocardium dry matter was also increased, but as a consequence of fortifying the feed with linseed oil, a rich source of $\alpha$-linolenic acid (n-3). It may be supposed that the Fe content is related to the myoglobin content, which in light of the obtained results would indicate an increase in the potential activity of the myocardium. The increased level of n-3 PUFA also affected the $\mathrm{Cr}$ content in the myocardium. In tissues, $\mathrm{Cr}$ is present in the form of glucose tolerance factor (GTF), a protein compound containing nicotinic acid with ligands of glutaminic acid, glycine and cysteine. GTF increases the effectiveness of binding insulin to cell membrane receptors, initiating its reaction with the sulphuric bond of transporting proteins. It was found that insulin activity is positively correlated with the content of long-chained PUFA n-3 in muscular phospholipids. The PUFA n-3 effect, among others, on the number of insulin receptors in cellular membranes would greatly explain the increase of demand for GTF (Luostarinen, 1995). The more effective supply of glucose to the cell may be an element favouring its inactivation. In the experiment, tendencies towards increased $\mathrm{S}$ and $\mathrm{Zn}$ contents, as affected by PUFA n-3 supplementation of the feed, were also observed. These results may be an indication of the stability of the antioxidative state of the organism because $\mathrm{Zn}$ is associated with peroxide dismutase (SOD), whereas sulphur is found in metalothioneins, containing sulphuric amino acids and glutathione.

\section{CONCLUSIONS}

The addition of $4 \%$ linseed oil to the ration increased the $\mathrm{Fe}$ and $\mathrm{Cr}$ content in myocardium dry matter in pigs, while fish by-product oil raised the $\mathrm{Mg}$ and $\mathrm{Cr}$ in the same tissue. 


\section{REFERENCES}

Bordoni A., Biagi P.L., Hrelia S., 1993. In: C.A. Drevon, I. Baksaas, H.E. Krokan (Editors). Omega3 Fatty Acids: Metabolism and Biological Effects. Birkhauser Verlag Basel/Switzerland, pp. $107-114$

Clamp A.G., Ladha S., Clark D.C., Grimble R.F., Lund E.K., 1997. The influence of dietary lipids on the composition and membrane fluidity of rat hepatocyte plasma membrane. Lipids 32, 172-184

Demaison L., Grynberg A., 1991. Influence of dietary linseed oil and suflower seed oil on some mechanical and metabolic parameters of isolated working rat heart. Reprod. Nutr. Develop. 31, $37-45$

Fernandes G., Venkatraman J.T., 1993. Role of omega - 3 fatty acids in health and disease. Nutr. Res. $13, \mathrm{~S} 19-\mathrm{S} 45$

Halliwel B., Gutteridge J.M., 1990. Role of free radicals and catalytic metal ions in human disease: an overwiew. Methods Enzymol. 186, 1-8

Lauridsen C., Karlson A.H., Henckel P., 1997. $\mathrm{Ca}^{2+}$-accumulation dependence on the muscle metabolic status. Proceedings of Food Science Congress, Copenhagen (Denmark)

Leibovitz B.E., Hu M.L., Tappel A.L., 1990. Lipid peroxidation in rat tissue slices: effect of dietary vitamin E, corn oil-lard and menhaden oil. Lipids 25, 125-129

Luostarinen R., 1995. Studies on n-3 Polyunsaturated fatty acids with special references to cardiovascular disease. Acta Univ. Upsaliensis, Uppsala (Sweden), p. 15

Nalbone G., Leonardi J., Termine E., Portugal H., Lechene P., Pauli A., Lafont H., 1989. Effect of fish oil, com oil and lard diets on lipid peroxidation status and glutathione peroxidase activities in rat heart. Lipids $24,179-186$

Reibel D.K., Holahan M.A., Hock C.E., 1988. Effects of dictary fish oil on cardiac responsiveness to adrenoreceptor stimulation. Amer. J. Physiol. 254, H494-H499

Shils M.E., 1997. Magnesium. In: B.L. O’Dell, A. Sunder (Editors). Handbook of Nutritionally Essential Mineral Elements. Marcel Dekker, New York, pp. 117-152

Ternouth J.H., 1990. Phosphorus and beef production in Northern Australia. III. Phosphorus in cattle - review. Trop. Grasslands 24, 159-169

\section{STRESZCZENIE}

\section{Wpływ diety wzbogaconej w wielonienasycone kwasy tluszczowe na zawartość wybranych pierwiastków w tkance mięśnia sercowego rosnących świń}

Doświadczenie przeprowadzono na 3 grupach tuczników (wbp x pbz), po 7 sztuk w każdej, utrzymywanych w indywidualnych kojcach przez $102 \mathrm{dni}$, od 25 do $102 \mathrm{~kg}$ masy ciała. Żywiono je mieszankami pełnoporcjowymi zawicrającymi następujące tłuszcze (4\%): smalec, olej lniany, olej rybny utylizacyjny. Po uboju zwierząt pobrano próbki tkanki serca i oznaczono w nich zawartość pierwiastków metodami spektrometrycznymi. Stwierdzono, że dodany do mieszanek olej lniany wpłynął na istotne $(\mathrm{P}<0,05)$ zwiększenie zawartości $\mathrm{Fe} \mathrm{i} \mathrm{Cr}$, a dodatek oleju rybnego zwiększył $(\mathrm{P}<0,05)$ zawartość $\mathrm{Mg}$ i $\mathrm{Cr}$ w suchej masie tkanki mięśnia sercowego świń. 